\title{
Relasjonens betydning i psykoterapi
}

\author{
Hvordan den terapeutiske relasjonen skal brukes i psykoterapi, er et hett tema både i Norge og internasjo- \\ nalt. Relasjonens betydning er vektlagt forskjellig i de forskjellige psykologiske teorier og innen terapifeltet. \\ Den terapeutiske relasjonen inneholder rasjonelle og irrasjonelle elementer. I kognitiv, relasjonell og psyko- \\ dynamisk terapi forstås og vektlegges relasjonens betydning i samtalebehandlingen forskjellig.
}

Espen Bjerke

espbje@so-hf.no

Det blir ofte hevdet at Sigmund Freud (1856-1939) bygde opp en énpersonspsykologi der individets drifter og driftshåndtering var det viktigste og der relasjonene kom $i$ annen rekke. Harry Stack Sullivan (18921949) regnes som grunnleggeren av interpersonlig teori. Han var preget av nyere vitenskapsteoretiske strømninger som positivisme, pragmatisme og operasjonalisme, det vil si at det er det sansbare, det praktisk anvendelige og operasjonaliserbare som gjelder også innen psykologi og psykiatri.

Disse strømningene, som sto sterkt i USA, sto i motsetning til europeisk forankret metafysikk, som innbefattet Freuds ideer om det intrapsykiske. Sullivan kritiserte Freuds definisjon av det individuelle sinn som den grunnenheten som skulle studeres og lanserte en annen modell for hvordan menneskene er skrudd sammen. Først og fremst hevdet han at mennesket av natur er dyadisk, i kontinuerlig samhandling med andre (1).

\section{Egopsykologien}

Egopsykologien, som var en direkte videreføring av den klassiske psykoanalytiske teorien, var lenge dominerende, særlig innen amerikansk psykoanalyse, fra 1950årene og utover. Mens Freud skildret egoet som en som ikke er herre i eget hus, som en rytter som tror han har kontroll over hesten, løsriver egopsykologien egoets opprinnelse fra driftene og tilskriver det primær autonomi (2).

Ego kan defineres som «det system av prosesser som modifiserer ytre og indre stimuli slik at den best mulige adaptive integrasjon oppnås til enhver tid» (3).

\section{Objektrelasjonspsykologien}

Motsetningene mellom det indre og det ytre ble nedtonet med objektrelasjonspsykologien, som gir plass for både det intrapsykiske og det relasjonelle - den indre verden er også en mellommenneskelig verden. Objektrelasjonspsykologien har utvidet våre teorier om hva som driver oss, hva som motiverer oss. Mennesket har helt fra fødselen en grunnleggende «drift» mot relasjoner til andre mennesker. Det er snakk om et tredje driftsbehov, et relasjonsbehov, ved siden av seksuelle og aggressive drifter $(4,5)$.

Man kan snakke om tre slags relasjonsbehov. For det første er det behovet for trygghet, der kvaliteten på den tidlige tilknytningen står sentralt (6). For det andre er det behovet for selvbekreftelse, det vil si behovet for emosjonell tilbakemelding som bekrefter følelsen av å være et «selv» («the gleam in the mother's eye») (7). Og endelig er det behovet for fellesskap (5, s. 44). Disse behovene kan være udekket i barndommen, på den ene eller andre måten. Dette vil da kunne komme til å prege den terapeutiske relasjonen.

\section{Relasjoner i psykoterapi}

I sin lærebok definerer Ralph Greenson (1911-79) overføring som en spesiell type relasjon. Den er kjennetegnet ved at følelsene overfor en person ikke helt passer $i$ forhold til den personen, men snarere er tilpasset en annen (8) - en person fra fortiden. Overføring er en repetisjon, en ny versjon av en gammel objektrelasjon.

Det var pasienten «Dora» som fikk Freud på sporet av overføringsfenomenet (9). Det dreide seg om hans erfaring med å bli gjenstand for unge kvinnelige pasienters beundring, betatthet og forelskelse. Dette valgte Freud ikke å ta «som gitt», siden han, som han sa, jo ikke var noen inntagende og sjarmerende person! Det måtte dreie seg om noe annet, for eksempel en reaktivering av en barnlig kjerne hos pasienten - barnet som trygler om fars oppmerksomhet og anerkjennelse.

Greenson omtaler også to andre relasjonelle begreper, nemlig «arbeidsalliansen» og «den virkelige relasjon». For å arbeide effektivt med sine problemer må pasienten etablere en annen relasjon til terapeuten ved siden av sine overføringsreaksjoner. Dette kaller han arbeidsalliansen.

Arbeidsalliansen består av den relativt unevrotiske, rasjonelle delen av pasientens relasjon til terapeuten og er en indikator på pasientens kapasitet til å arbeide målrettet $\mathrm{i}$ terapien. Greenson hevdet at arbeidsalliansen måtte anses som like betydningsfull som overføringsreaksjonene i terapeutpasient-relasjonen. Det er nå et godt kunnskapsgrunnlag for å mene at arbeidsalliansen, også kalt den terapeutiske alliansen, er den sterkeste og mest konsistente prediktoren for behandlingsutfallet (10).

Alliansen vil kunne svekkes når pasienten, på bakgrunn av sine livserfaringer, har lave forventninger til behandlingen, en fiendtlig mellommenneskelig innstilling og usikker tilknytning. Terapeuten kan bidra til å styrke arbeidsalliansen via teknisk dyktighet, fleksibilitet og evnen til å regulere negative følelser - $\mathrm{i}$ tillegg til sensitivitet for interpersonlige prosesser, at behandlingen oppfattes som lite kritisk og krevende, og at den verken er over- eller understrukturert (10).

Den tredje typen terapeutisk relasjon kaller Greenson «den virkelige relasjonen». Det belyses med kliniske eksempler, der hovedpoenget er at problematiske trekk hos terapeuten eller ukloke intervensjoner fra terapeutens side kan utløse realistiske reaksjoner hos pasienten. Disse må erkjennes som reelle av terapeuten, snarere enn å gjøres til gjenstand for motstands- eller overføringstolkninger.

En annen definisjon av arbeidsalliansen, foreslått av Bordin, er at den består av tre elementer: kontakten eller det emosjonelle båndet mellom terapeut og pasient, enighet om målet for terapien og enighet om hvilke oppgaver som må løses for å nå målet (11). En slik definisjon vil kunne innebære at elementer av Greensons to øvrige relasjonstyper (overføring og virkelig relasjon) blir innbefattet $i$ arbeidsalliansebegrepet. Det blir derfor viktig å klargjøre hvilket alliansebegrep man snakker om når man skal diskutere arbeidsalliansens betydning.

\section{Fellesfaktorer?}

Det er en utbredt oppfatning innen psykoterapiforskningen $\mathrm{i}$ dag at det er lite som skiller de forskjellige retningene når det 


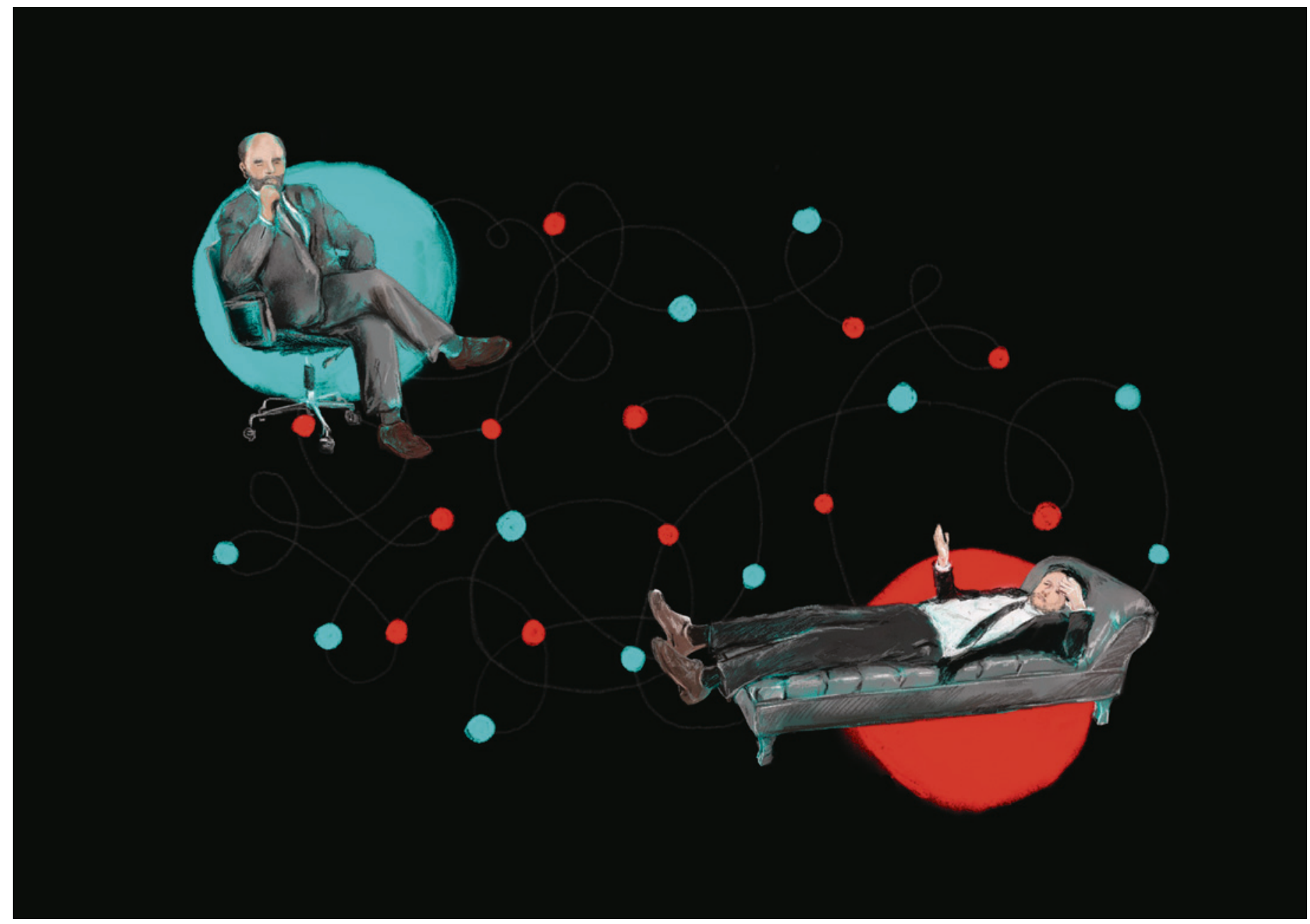

Illustrasjon: Sylvia Stølan

gjelder terapeutisk effekt. Snarere er det de såkalte fellesfaktorer, for eksempel terapeutisk allianse, empati, respekt, terapeutens oppmerksomme nærvær og så videre som er det avgjørende (12). Det kan imidlertid være vanskelig å skille fellesfaktorer fra de teknikker og endringsmekanismer som er spesifikke for de ulike behandlingsformene. Selv om noen terapeuter kan ha medfødte evner når det gjelder å hanskes med disse faktorene, er det også mulig å lære dem, for eksempel ved å skaffe seg kompetanse $\mathrm{i}$ å håndtere overføring og egne reaksjoner på pasienten (motoverføring) - noe som gir en spesifikk relasjonell kompetanse (13).

Særlig når det gjelder å styrke evnen til å regulere negative følelser, er det trolig en fordel med egenbehandling, slik at terapeuten får anledning til å få mer klarhet i sine egne ømme punkter.

\section{Et spektrum av terapiformer}

I alle former for psykoterapi er mellommenneskelige relasjoner helt sentralt, mens det er forskjeller når det gjelder vektlegging av relasjonen i terapien - i hvilken grad den terapeutiske relasjonen blir benyttet som arbeidsredskap.

I den ene enden av spekteret finner vi kognitiv atferdsterapi, der man tradisjonelt har vært mindre opptatt av den terapeutiske relasjonen så lenge den anses som god nok (14). I den andre enden av spekteret befinner de intersubjektive/relasjonelle terapiformene seg, der man hovedsakelig er opptatt av relasjonen her og nå. Den samskapte relasjonen utforskes i fellesskap uten at terapeuten inntar en mer objektiv posisjon enn pasienten eller en ekspertposisjon (15).

Mellom disse posisjonene mener jeg at vi finner de psykodynamiske terapiene, der man bruker terapirelasjonen som et viktig arbeidsredskap, samtidig som man ikke gir opp ideen om den «objektive» betrakter. På grunnlag av sin ekspertise og erfaring og gjennom selvrefleksjon har terapeuten mulighet for å skape tilstrekkelig distanse til å kunne observere hva som foregår mellom terapeut og pasient. Det gjør det mulig å kunne komme med klargjørende, påpe- kende og konfronterende innspill og tolkningsforslag.

\section{Eksempler fra forskningen}

Et eksempel kan belyse hva svikt i den terapeutiske relasjonen kan føre til, nærmere bestemt hvordan terapeutens mangelfulle oppmerksomhet og håndtering av pasientens overføring og egen motoverføring fører til dårlig resultat. To grupper med pasienter fra den store norske multisenterstudien omkring prosess og utfall i psykoterapi ble undersøkt (16). I den ene gruppen var utfallet godt, i den andre var det dårlig eller uforandret utfall. I ettertid synes sistnevnte gruppe å være kjennetegnet av at disse pasientene mer eller mindre subtilt avviste terapeutens forsøk på å være hjelpsom. En vedvarende avvisning av å anerkjenne terapeutens kompetanse gjorde trolig denne mer utsatt for å reagere med mer eller mindre subtil fiendtlighet og avvisning tilbake. Dette ble antatt å være hovedårsaken til det dårlige utfallet for disse pasientene (17). 
Et annet eksempel er fra en randomisert klinisk studie hvor man undersøkte hva systematisk oppmerksomhet på overføring gjorde med behandlingen sammenlignet med behandling der overføring ikke ble vektlagt. I begge gruppene ble det lagt vekt på relasjoner - i den ene hovedsakelig på relasjoner utenfor terapirommet, mens man i den andre konsekvent trakk det relasjonelle inn i terapirommet: «Hvordan er det her?» (18). Et av hovedfunnene var at de mest forstyrrede pasientene viste seg å ha best utbytte av oppmerksomhet på den terapeutiske relasjonen, altså overføringsarbeid.

\section{Aktør i eget liv}

I forskjellige terapiformer vektlegges forskjellige sider av det relasjonelle. Hvilken vei man velger, vil avhenge av en rekke pasient- og terapeutfaktorer, hvilken situasjon man befinner seg i og hvilken målsetting man har for behandlingen. Mange pasienter har ikke noe dypt ønske om å forstå seg selv bedre, de ønsker snarere kun å bli kvitt sine symptomer. Andre føler mer behov for å mestre sine plager og problemer gjennom å bli bedre kjent med seg selv.

Det kan hevdes at noen terapiformer er endringsfokuserte, mens andre er mer undringsfokuserte. Målet vil i siste instans være det samme: Å bli bedre til å stå på egne ben og til å like seg selv og andre!
Manuskriptet er en omarbeidet og forkortet versjon av forfatterens prøveforelesning ved forsvar av ph.d.-graden ved Universitetet i Oslo 8.4. 2016.

\section{Espen Bjerke (f. 1947)}

er spesialist i psykiatri, ph.d., psykoanalytiker og psykoterapiveileder ved Sykehuset Østfold Forfatter har fylt ut ICMJE-skjemaet og oppgir ingen interessekonflikter.

\section{Litteratur}

1. Mitchell SA. The intrapsychic and the interpersonal: Different theories, different domains, or historical artifacts? Psychoanal Inq 1988; 8: 472-96.

2. Hartmann $\mathrm{H}$. Ego psychology and the problem of adaptation. New York: International Universities Press, 1939/1958.

3. Killingmo B. Rorschachmetode og psykoterapi. En egopsykologisk studie. Oslo: Universitetsforlaget, 1980: 43

4. Greenberg JR, Mitchell SA. Object relations in psychoanalytic theory. Cambridge, MA: Harvard University Press, 1983

5. Gullestad SE, Killingmo B. Underteksten. Psykoanalytisk terapi i praksis. 2. utg. Oslo: Universitetsforlaget, 2013

6. Bowlby J. A secure base: parent-child attachment and healthy human development. London: Routledge, 1988.

7. Kohut H, Wolf E. The disorders of the self and their treatment: An outline. Int J Psychoanal 1978; 59: 413-26.

8. Greenson RR. The technique and practice of psychoanalysis. London: The Hogarth Press, 1978.

9. Freud S. Three essays on the theory of sexuality.
SE vol. VII 1901-1905. London: The Hogarth Press, 1953: 3-122.

10. Muran JC, Barber JP, red. The therapeutic alliance: an evidence-based guide to practice. New York: Guilford Press, 2010.

11. Bordin ES. The generalizability of the psychoanalytic concept of the working alliance. Psychotherapy 1979; 16: 252-60

12. Wampold BE. The great psychotherapy debate. Models, methods, and findings. Mahwah, NJ: Lawrence Erlbaum Associates, 2001

13. Gullestad SE. Er fellesfaktorer alternativet? Tidsskrift for Norsk psykologforening 2015; 52 : $896-906$

14. Beck AT, Rush AJ, Shaw BF et al. Cognitive therapy of depression. New York: The Guilford Press, 1979.

15. Holmqvist R. Relationell psykoterapi - så här gör man. Malmö: Liber, 2010

16. Havik OE, Monsen JT, von der Lippe A et al. Multisenterprosjekt for studier av prosess og utfall i psykoterapi. Prosjektbeskrivelse. Oslo: Universitetet i Oslo, 1995

17. von der Lippe AL, Monsen JT, Rønnestad MH et al. Treatment failure in psychotherapy: the pull of hostility. Psychother Res 2008; 18: 420-32

18. Høglend P, Amlo S, Marble A et al. Analysis of the patient-therapist relationship in dynamic psychotherapy: an experimental study of transference interpretations. Am J Psychiatry 2006; 163: $1739-46$.

Mottatt 9.5. 2016, første revisjon innsendt 21.7. 2016, godkjent 13.10. 2016. Redaktør: Ketil Slagstad.

Engelsk oversettelse på www.tidsskriftet.no

\section{Instruksjonsfilmer på www.felleskatalogen.no}

Se etter film-symbolene øverst i Felleskatalogtekstene.

罡 Blått for helsepersonell, og rødt for pasient! 䁅

Skann QR-kode for filmoversikt:

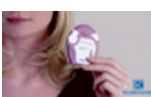

